\title{
ANALISIS BIAYA PENGENDALIAN PERSEDIAAN BAHAN BAKU DALAM MENINGKATKAN VOLUME PRODUKSI PADA PERUSAHAAN AGAR-AGAR CAP APEL
}

\author{
Revanti $^{1}$ \\ Arga Sutrisna ${ }^{2}$ \\ Email: revanti900@gmail.com \\ Universitas Perjuangan Tasikmalaya ${ }^{1,2}$
}

\begin{abstract}
Abstrak
Tujuan penelitian ini adalah untuk mengetahui dan menganalisis hubungan variabel biaya pengendalian persediaan bahan baku dalam meningkatkan volume produksi. Metode penelitian yang digunakan adalah metode kualitatif dan data yang digunakan adalah data sekunder yang diperoleh langsung melalui wawancara dengan pemilik perusahaan. Dalam penelitian ini, pengambilan sampel menggunakan pendekatan data berkala dengan skala bulanan yaitu 36 bulan. Apa yang diteliti oleh penulis terdiri dari satu variabel bebas dan satu variabel terikat maka alat analisis yang paling tepat adalah regresi linier sederhana. Berdasarkan hasil analisis regresi linier sederhana diketahui bahwa biaya pengendalian persediaan bahan baku memiliki pengaruh signifikan terhadap volume produksi. Hali ini juga dapat dilihat dari data perusahaan bahwa setiap kenaikan pada biaya pengendalian persediaan bahan baku maka volume produksi juga mengalami peningkatan. Hasil perhitungan menunjukkan bahwa terdapat hubungan yang sangat erat antara variabel biaya pengendalian persediaan bahan baku dalam meningkatkan volume produksi.
\end{abstract}

\section{Kata kunci: Biaya pengendalian persediaan bahan baku, volume produksi}

\begin{abstract}
The purpose of this study was to determine and analyze the relationship between the cost of controlling raw material inventory variables in increasing production volume. The research method used is a qualitative method and the data used is secondary data obtained directly through interviews with company owners. In this study, sampling used a periodic data approach on a monthly scale, namely 36 months. What the writer examines consists of one independent variable and one dependent variable, so the most appropriate analysis tool is simple linear regression. Based on the results of simple linear regression analysis, it is known that the cost of controlling raw material inventories has a significant effect on production volume. This can also be seen from company data that each increase in the cost of controlling raw material inventories, the production volume also increases. The
\end{abstract}


p-ISSN : 2714-8319,e-ISSN: 2714-7452

calculation results show that there is a very close relationship between the variable costs of controlling raw material inventories in increasing production volume.

\section{Keywords: Cost of controlling raw material inventory, production volume}

\section{PENDAHULUAN}

Untuk memenuhi kebutuhan nya manusia memerlukan barang dan jasa. Suatu kegiatan/aktivitas yang menghasilkan barang dan jasa disebut produksi. Menurut Agus Ristono (2013:1) Persediaan dapat diartikan sebagai barang-barang yang disimpan untuk digunakan atau dijual pada masa atau periode yang akan datang. Persediaan terdiri dari persediaan bahan baku, persediaan bahan setengah jadi dan persediaan barang jadi. Persediaan bahan baku dan bahan setengah jadi disimpan sebelum digunakan atau dimasukan ke dalam proses produksi, sedangkan persediaan barang jadi atau barang dagangan disimpan sebelum dijual atau dipasarkan. Dengan demikian setiap perusahaan yang melakukan kegiatan usaha umumnya memiliki persediaan. Proses produksi dapat berjalan apabila ada persediaan bahan baku sesuai dengan kapasitas produksi setiap harinya. Persediaan bahan baku yang cukup dapat memperlancar proses produksi. Agar kegiatan produksi dapat memperoleh hasil yang sesuai dengan yang diinginkan, maka diperlukan adanya pengendalian persediaan bahan baku. Pengendalian persediaan bahan baku merupakan suatu masalah yang sering dihadapi oleh suatu perusahaan, dimana sejumlah barang diharapkan dapat diperoleh pada tempat dan waktu yang tepat. Persediaan berperan penting bagi perusahaan.

Perusahaan Agar-Agar Cap Apel adalah satu-satunya produsen pemasok agar-agar dari Kabupaten Garut yang sudah terkenal ke seluruh Jawa Barat bahkan Indonesia. Agar- agar kertas ini merupakan salah satu produk khas dari wilayah Kabupaten Garut dengan berbahan dasar dari rumput laut sebagai komoditi utama yang mempunyai nilai ekonomis tinggi di pantai selatan. Yang menjadi permasalahan dalam proses produksi agar-agar kertas ini yaitu bahan baku yang digunakan hanya dihasilkan pada saat musim kemarau saja. Dengan kata lain bahan baku yang digunakan hanya dipanen 1 tahun sekali saat musim kemarau, sehingga perusahaan harus mengadakan pengendalian persediaan bahan baku selama musim hujan untuk memperlancar proses produksi dan meningkatkan volume produksi. Berdasarkan hasil survei di lapangan ditemukan permasalahan tentang volume produksi yang ada pada Perusahaan Agar-Agar Cap Apel. Hal ini diindikasikan pada proses produksi yang terus menerus yaitu bahan baku yang digunakan hanya ada atau tersedia ketika musim kemarau dan bahan baku tidak bisa didapatkan ketika musim penghujan. Dalam kurun waktu 3 tahun volume produksi Perusahaan Agar- Agar Cap Apel ini terus meningkat sejalan dengan meningkatnya biaya pengendalian persediaan bahan baku. Dari data yang didapatkan penulis pada saat penelitian 
maka penulis tertarik untuk mengambil judul skripsi "Analisis Biaya Pengendalian Persediaan Bahan Baku Dalam Meningkatkan Volume Produksi”

\section{TINJAUAN PUSTAKA}

Persediaan merupakan bagian utama dari modal kerja, sebab dilihat dari jumlahnya biasanya persediaan inilah unsur modal kerja yyang paling besar. Tanpa adanya persediaan kemungkinan besar perusahaan tidak bisa memperoleh keuntungan yang diinginkan disebabkan proses produksi akan terganggu. (Jay Heizer dan Berry Render, 2015:84) Menurut Heizer and Render (2010:82), Keempat fungsi persediaan adalah sebagai berikut:

1. Decouple atau memisahkan beberapa tahapan dari proses produksi.

2. Melakukan decouple perusahaan dari fluktuasi permintaan

3. Mengambil keuntungan dari diskon kuantitas

4. Melindungi terhadap inflasi dan kenaikan harga

Menurut T. Hani Handoko (2010:336) Biaya pengendalian persediaan bahan baku adalah: "Biaya-biaya yang mempengaruhi pengambilan keptusan dalam menentukan besarnya jumlah persediaan." Definisi persediaan menurut Assauri (2016:225) adalah: "Persediaan (Inventory) adalah stok dari suatu item atau sumber daya yang digunakan dalam suatu organisasi perusahaan." Persediaan menurut Haming dan Nurnajmudin (2014:4) yaitu: "Persediaan adalah sumber daya ekonomi fisik yang perlu diadakan dan dipelihara untuk menunjang kelancaran produksi, meliputi bahan baku, produk jadi, komponen rakitan, bahan pembantu dan barang sedang dalam proses pengerjaan." Setiap perusahaan apakah itu perusahaan perdagangan atau pabrik serta perusahaan jasa selalu mengadakan persediaan. Persediaan merupakan komponen utama dalam perusahaan yang bergerak dibidang produksi dan distribusi tentu membutuhkan suatu sistem yang mengatur persediaan tersebut untuk menghindari terjadinya penumpukan maupun kekurangan persediaan. (Assauri, 2016:225).

Tujuan pengendalian persediaan menurut Eric Damanik (2016) antara lain:

1. Menjaga agar barang dagangan jangan sampai kekurangan.

2. Menjaga agar perusahaan jangan sampai menghentikan kegiatan usahanya. Menjaga agar perusahaan jangan sampai mengecewakan langganannya.

3. Mengatur jangan sampai jumlah pengadaan barang dagangan kekurangan atau kelebihan.

Menurut T. Hani Handoko (2010:336) adapun yang menjadi indikator dari biaya pengendalian persediaan baha baku yaitu:

1. Biaya Pemesanan 
Biaya yang dikeluarkan sehubungan dengan kegiatan pemesanan barang/bahan, sejak dari penempatan pemesanan sampai tersedianya barang di gudang. Biaya pemesanan ini meliputi semua biaya yang dikeluarkan dalam rangka mengadakan pemesanan.

\section{Biaya Penyimpanan}

Biaya yang dikeluarkan berkenaan dengan diadakannya persediaan barang. dihasilkan dalam perusahaan melalui proses produksi menjadi output yang diinginkan. Volume produksi yang biasa juga disebut hasil produksi adalah suatu barang yang dihasilkan melalui serangkaian kegiatan dalam proses produksi. Barang dan jasa yang dihasilkan selanjutnya dikemas untuk disalurkan kepada konsumen. Menurut Indriyo dalam Astutik (2014:38) Volume produksi adalah: "Volume produksi adalah interaksi antara bahan dasar, bahan pembantu, tenaga kerja dan mesin-mesin serta alat- alat perlengkapan yang dipergunakan". Menurut Safuan (2017:115) Volume produksi yaitu: "Peningkatan volume pecapaian jumlah produksi”. Menurut Stapelton (2011:137) mengatakan bahwa: "Volume produksi adalah pencapaian produksi yang dinyatakan dalam bentuk kuantitatif dari segi fisik maupun volume”. Berdasarkan pengertian- pengertian diatas maka penulis dapat mengambil sebuah kesimpulan bahwa yang dimaksud dengan volume produksi adalah jumlah barang yang telah terproduksi dalam sebuah perusahaan. Menurut Stepelton (2011:137) Volume produksi adalah pencapaian produksi yang dinyatakan dalam bentuk kuantitatif dari segi fisik maupun volume. Adapun indikator dari volume produksi yaitu jumlah produk yang dihasilkan.

\section{METODE PENELITIAN}

Metode yang digunakan dalam penelitian ini adalah metode penelitian kualitatif dengan pendekatan induktif. Data penelitian ini menggunakan data sekunder dengan teknik pengumpulan data melalui wawancara, studi dokumen dan observasi langsug dengan jenis data runtut waktu (time series) dari periode tahun 2017-2019. Data dikumpulkan langsung dari Perusahaan Agar-Agar Cap Apel diantaranya data biaya pengendalian persediaan bahan baku dan volume produksi. Data selanjutnya dianalisis sesuai dengan tujuan penelitian menggunakan analisis regresi linier sederhana. Model analisis regresi linier sederhana pada penelitian ini dapat digambarkan sebagai berikut:

$$
\mathrm{Y}=\mathrm{a}+\mathrm{bX}+\mathrm{e}
$$

$\mathrm{Y}=$ Volume Produksi

$\mathrm{a}=$ Harga $\mathrm{Y}$ bila $\mathrm{X}=0$

$\mathrm{b}=$ angka arah atau koefisien regresi, yang menunjukkan angka peningkatan ataupun penurunan variabel independen. Bila b (+) maka naik dan bila (-) terjadi 
penurunan.

$\mathrm{X}=$ Variabel bebas (Biaya Pengendalian Persediaan Bahan Baku)

$\mathrm{e}=$ error atau sisa

\section{HASIL PENELITIAN DAN PEMBAHASAN}

Pengendalian persediaan bahan baku merupakan bagian utama dari modal kerja. Bisa dikatakan tidak ada perusahaan yang beroperasi tanpa adanya persediaan. Persediaan dapat berupa bahan mentah, bahan pembantu, barang dalam proses, barang jadi maupun suku cadang. Dalam hal ini Perusahaan Agar-Agar Cap Apel menggunakan bahan mentah agar-agar jarum merah dan agar-agar katoni sebagai bahan baku utama yang digunakan dalam proses produksi. Pengendalian persediaan bahan baku pada Perusahaan Agar- Agar Cap Apel terbilang cukup sederhana karena tidak ada biaya lain-lain selain biaya pemesanan dan biaya pemeliharaan bahan baku. Untuk biaya pengendalian persediaan bahan baku pada Perusahaan Agar- Agar Cap Apel ini merupakan biaya keseluruhan bahan baku dari gudang ke tempat pengolahan. Dalam kurun waktu 3 tahun biaya pengendalian persediaan bahan baku yang dikeluarkan oleh Perusahaan Agar-Agar Cap Apel ini terus meningkat setiap tahunnya hal ini karena di dukung oleh beberapa faktor yang memungkinkan untuk melakukan proses produksi secara terus menerus. Untuk biaya pemesanan ini merupakan harga gudang yang sudah diantarkan ke tempat pengolahan bahan, jadi tidak ada biaya operasional lain yang dikeluarkan oleh perusahaan.

Pengeluaran tertinggi ini disebabkan karena ketersediaan bahan baku yang memadai sehingga memungkinkan perusahaan untuk terus melakukan proses produksi yang kemudian menyebabkan peningkatan volume produksi. Pengeluaran terendah ini disebabkan karena pada saat itu bahan baku yang digunakan tidak tersedia dalam jumlah yang cukup karena bahan baku gagal panen sehingga membuat proses produksi terganggu dan mengakibatkan menurunnya volume produksi. Untuk menghasilkan produk yang baik dari segi kualitas dan kuantitas, perlu adanya perencanaan dalam membuat suatu produk mengenai berapa banyak produk yang akan dihasilkan agar sesuai dengan target yang ditentukan. Volume produksi atau yang biasa disebut hasil produksi adalah suatu barang yang dihasilkan melalui serangkaian kegiatan dalam proses produksi. Volume produksi adalah hasil akhir dari keseluruhan proses produksi yang dilakukan oleh Perusahaan Agar-Agar Cap Apel, dalam hal ini yaitu realisasi produksi. Data yang dianalisis adalah berdasarkan realisasi produksi yaitu total seluruh jumlah produk yang dihasilkan perusahaan per bulan. Volume produksi sangat bergantung terhadap proses produksi, karena jika proses produksinya berjalan lancar, maka volume produksi atau hasil produksi nya akan optimal dan sesuai dengan apa yang direncanakan perusahaan. Begitupun proses produksi sangat tergantung dengan ketersediaan bahan baku, karena jika tidak ada bahan baku atau bahan baku tidak sesuai dengan 
kebutuhan maka proses produksi akan terganggu dan hasil produksi tidak akan sesuai dengan apa yang direncanakan perusahaan.

Dalam kurun waktu 3 tahun volume produksi Perusahaan Agar- Agar Cap Apel ini terus meningkat sejalan dengan meningkatnya biaya pengendalian persediaan bahan baku. Dalam hal ini dapat kita lihat bahwa hubungan antara biaya pengendalian persediaan bahan baku dan volume produksi adalah sejalan, karena saat biaya pengendalian persediaan bahan baku naik maka total volume produksi ikut naik, begitupun sebaliknya jika biaya pengendalian persediaan bahan baku menurun maka total volume produksi pun ikut mengalami penurunan. Pendapatan tertinggi perusahaan disebabkan karena ketersediaan bahan baku yang memadai sehingga perusahaan terus melakukan proses produksi yang kemudian menyebabkan peningkatan volume produksi. Sedangkan pendapatan terendah ini disebabkan karena pada saat itu bahan baku yang digunakan tidak tersedia dalam jumlah yang cukup karena bahan baku gagal panen sehingga membuat proses produksi terganggu dan mengakibatkan menurunnya volume produksi. Pada Juni 2017 terjadi peningkatan secara drastis yang terjadi pada perusahaan dimana volume produksi meningkat sebanyak $315 \mathrm{~kg}$ dari $455 \mathrm{~kg}$ menjadi $770 \mathrm{~kg}$ dengan bruto sebesar Rp. 84.700.000,- hal ini disebabkan oleh adanya peningkatan dari hasil proses produksi karena ketersediaan bahan baku yang memadai sehingga perusahaan terus menerus melakukan proses produksi untuk memenuhi kebutuhan pasar. Sedangkan untuk September 2018 dan November 2019 terjadi penurunan yang cukup tinggi, hal ini disebabkan karena bahan baku utama yang digunakan gagal panen sehingga mengakibatkan penurunan volume produksi secara drastis.

Berdasarkan hasil analisis regresi sederhana didapatkan model persamaan regresi sebagai berikut:

$$
\mathrm{Y}=1.011+1.014(\mathrm{x})
$$

Persamaan diatas dapat diartikan sebagai berikut:

1. Nilai konstanta menunjukkan sebesar 1.011, apabila nilai biaya pengendalian persediaan bahan baku 0 maka nilai volume produksi sebesar 1.011 .

2. Variabel biaya pengendaian persediaan bahan baku memiliki nilai koefisien regresi sebesar 1.014 dan bertanda positif yang artinya memiliki hubungan searah.

Hal ini menunjukkan bahwa setiap kenaikan sebesar satu satuan maka volume produksi tidak diteliti oleh peneliti yaitu proses produksi, perencanaan produksi, pendapatan, dan biaya pemeliharaan. Dari output diatas dapat diketahui t hitung = 149,720 lebih besar dari t tabel $=2,035$ maka Ho ditolak Ha diterima, berarti ada 
pengaruh signifikan dari variabel Biaya Pengendalian Persediaan Bahan Baku dalam meningkatkan Volume Produksi. Pengambilan keputusan dalam uji regresi linier sederhana dapat dilihat pada nilai signifikan :

1. Jika nilai signifikansi $<0,05$, artinya variabel $\mathrm{X}$ berpengaruh signifikan terhadap variabel Y.

2. Jika nilai signifikansi $>0,05$, artinya variabel $\mathrm{X}$ berpengaruh tidak signifikan terhadap variabel $\mathrm{Y}$. Berdasarkan hasil analisis

Regresi sederhana dan pengujian hipotesis menunjukkan bahwa biaya pengendalian persediaan bahan baku berpengaruh signifikan dalam meningkatkan volume produksi. Biaya pengendalian persediaan bahan baku dinyatakan berpengaruh signifikan dalam meningkatkan volume produksi dilihat dari signifikansi yang diperoleh sebesar 0,000 lebih kecil dari 0,05. Nilai Sig. $=0,000$ berarti Sig. $<$ dari kriteria signifikan $(0,05)$. Hasil penelitian ini menunjukkan hasil yang sejalan dengan penelitian Dedi Joko Hermawan (2018) dalam hal ini biaya pengendalian persediaan bahan baku berpengaruh signifikan dalam meningkatkan volume produksi. Penelitian ini juga sejalan dengan penelitian Indra dan Gina (2020) yangmenjelaskan bahwa persediaan bahan baku berpengaruh secara simultan dan parsial terhadap volume produksi. Maka dapat disimpulkan bahwa variabel biaya pengendalian persediaan bahan baku mempunyai pengaruh yang signifikan terhadap volume produksi. Semakin baik pengelolaan biaya pengendalian persediaan bahan bakunya maka semakin meningkat volume produksinya. Dalam suatu penelitian tentunya hasil penelitian yang disajikan tidak terlepas dari keterbatasan-keterbatasan yang menyebabkan hasil suatu penelitian tidak sempurna, begitu pula dengan penelitian ini yang meneliti tentang biaya pengendalian persediaan bahan baku dalam meningkatkan volume produksi. Keterbatasan itu adalah informasi yang didapat oleh penulis dari narasumber sangat minim sekali, sehingga penulis kesulitan untuk mengolah data yang ada.

\section{SIMPULAN}

\section{Kesimpulan}

Berdasarkan hasil penelitian dan pembahasan mengenai analisis biaya pengendalian persediaan bahan baku dalam meningkatkan volume produksi pada Perusahaan Agar-Agar Cap Apel Garut, dapat disimpulkan sebagai berikut: Pengeluaran terendah ini disebabkan oleh bahan baku yang gagal panen sehingga membuat proses produksi terganggu dan mengakibatkan menurunnya volume produksi. Berdasarkan hasil perhitungan SPSS bahwa Biaya Pengendalian Persediaan Bahan Baku berpengaruh signifikan dalam meningkatkan Volume Produksi pada Perusahaan Agar-Agar Cap Apel. Hal ini bersumber dari data 
laporan keuangan Perusahaan agar- Agar Cap Apel Garut periode tahun 2017 sampai dengan 2019

\section{Saran}

Adapun saran dalam penelitian ini adalah sebagai berikut:

1. Bagi Perusahaan Perusahaan dapat analisis untuk jumlah pembelian bahan baku yang optimal dan total biaya persediaan pada tahun tahun berikutnya apakah sudah efisien atau belum.

2. Bagi peneliti selanjutnya diharapkan dapat melakukan penelitian yang sifatnya pengembangan dan perbaikan, sehingga dapat menambah wawasan mengenai topik yang diteliti. Peneliti selanjutnya bisa menambah variabel lain menggunakan perhitungan mengetahui seperti lokasi usaha (Gelar Ananda (2020) yang berjudul Pengaruh Faktor Lokasi Usaha Terhadap Volume Produksi Pada Usaha Warung Kopi Di Kota Malang), faktor produksi dan pendapatan (R. Sinaga, D. Wijayanto dan Sardiyatmo (2014) yang berjudul Analisis Pengaruh Faktor Produksi Terhadap Pendapatan dan Volume Produksi Nelayan Centrang Di Pelabuhan Perikanan Nusantara Brondong Lamongan Jawa timur), serta menambahkan periode pengamatan yang lebih panjang dengan tujuan untuk memperoleh hasil yang lebih baik, sehingga dapat diketahui indikator-indikator biaya pengendalian persediaan bahan baku dalam meningkatkan volume produksi.

\section{DAFTAR PUSTAKA}

Ananda ,Gelar. 2020. Pengaruh Faktor Lokasi Usaha Terhadap olume Produksi Pada Usaha Warung Kopi Di Kota Malang. Jurnal. http://eprints.umm.ac.id/59663/ diakses pada 02 September 2020.

Assauri, Sofjan. 2016. Manajemen Operasi Produksi. Edisi 3. Jakarta: Rajawali Pers.

Astutik, Ita Zuli. 2014. Pengaruh Jumlah Persediaan Bahan

Baku, Kapasitas Mesin Dan Jumlah Tenaga Kerja Terhadap Volume Produksi Pada CV. Sanyu Paint Tropodo sidoarjo. Jurnal Bisnis Indonesia. Vol 5. No.1 April 2016

Damanik, Eric. 2016. Pengertian Persediaan Bahan Baku. E book. Kumpulan Ilmu,

Haming, Murdifin. dan Nurnajamuddin Mahmud. 2014. Manajemen Produksi Modern. edisi 2. Penerbit Bumi Aksara. 
Heizer, Jay, and Barry, Rander.

2010. Operation Manajemen- Manajemen Operasi. Buku 1. Edisi 9. Jakarta : Penerbit Salemba Empat.

Heizer, Jay dan Barry Render. 2015. Operations Management (Manajemen Operasi) ed 11. Terjemahan Dwi Anoegrah Wati dan Indra Almahdy. Jakarta : Salemba Empat.

Hermawan, Dedi Joko. 2018. Pengaruh Jumlah Persediaan Bahan Baku dan Kapasitas Mesin Terhadap Volume Produksi Pada UD Cahaya Restu Kota Probolinggo. Skripsi. Probolinggo: Universitas Probolinggo. Panca Marga

I.C. Kusuma, G. Pebrianti. 2020. Pengaruh Persediaan Bahan Baku dan jam Mesin Terhadap Volume Produksi Pada PT. Yongjin Garment Fact 1. https://unida.ac.id/ojs/JAKD/ar ticle/view/2813/pdf diakses pada 02 september 2020

R. Sinaga, D. Wijayanto, dan Sardiyatmo. 2014. Analisis Pengaruh Faktor Produksi Terhadap Pendapatan Dan Volume Produksi Nelayan Cantrang Di Pelabuhan Perikanan Nusantara (PPN) Brondong Lamongan Jawa Timur. Journal of Fisheries Resources Utilization Management and Technology, vol. 3. no. 2. https://ejournal3.undip.ac.id/in dex.php/jfrumt/article/view/50 38 diakses pada 02 September 2020

Ristono, Agus. 2013. Manajemen Persediaan. Yogyakarta: Graha Ilmu.

Safuan. 2017. Jurnal Inspirasi Bisnis dan Manajemen.Vol. 2. Jakarta

Stapelton, Hartson. 2011. Manajemen Pemasaran dan Bisnis edisi 5. Jakarta: Ghalia Indonesia

T. Hani, Handoko. 2011. Dasar - Dasar Manajemen Produksi dan Operasi. Yogyakarta: BPFE. 